\title{
Aristotle on the Naturalness of Death from Old Age
}

\author{
Aristoteles'in Yaşlanarak Ölmenin Doğallı̆̆ı Üzerine Görüşü
}

\section{Tufan KIYMAZ*}

\begin{abstract}
In this work, I explore and critically evaluate Aristotle's views on the naturalness of dying from old age. His views are not straightforward, because Aristotle regards old age as a kind of decay and he talks about decay sometimes as natural and sometimes as unnatural. Nature, according to Aristotle, has two aspects, matter and form. I argue that, in Aristotle's system, decay is always materially natural but formally unnatural. Likewise, natural death is death caused by old age and although getting old is never formally natural, it is, in a particular sense, materially natural. In Aristotle's view, getting old does not have the same mechanism as inorganic decay such as wine's turning into vinegar, but it is a result of the materially natural decay of lungs, which leads to the exhaustion of the vital heat in the heart.
\end{abstract}

Keywords: Aristotle, Formal Nature, Material Nature, Old Age, Death

Öz: Bu çalışmada, Aristoteles'in yaşlanarak ölmenin doğallığı hakkındaki görüşlerini ortaya koyuyor ve irdeliyorum. Aristoteles'in ölümün doğallığı hakkındaki görüşleri pek açık olmamakla birlikte, yaşlılığı bir tür çürüme olarak değerlendirmesi ve çürümeyi yazılarının bir kısmında doğal bir kısmında ise yapay olarak nitelendirmesi yaşlanarak ölmenin Aristoteles felsefesindeki yerini sorunsallaştırıyor. Aristoteles'e göre doğallığın iki yönü vardır: bir şey maddi ya da formel olarak doğal olabilir. Bu makalede Aristoteles'in sisteminde çürümenin asla formel olarak değil, fakat her zaman maddi olarak doğal olduğunu iddia ediyorum. Buna göre, doğal ölüm yaşlılıktan kaynaklanan ölümdür ve yaşlanma formel olarak doğal olmasa da, kendine özgü bir şekilde, maddi olarak doğaldır. Aristoteles'e göre yaşlanmak şarabın sirkeye dönüşmesinde rol oynayan inorganik çürümeden farklı bir mekanizmaya sahiptir: akciğerlerin maddi olarak doğal olan çürümesi kalpte bulunan hayati ateşin yanarak tükenmesine ve dolayısıyla ölüme yol açar.

Anahtar sözcükler: Aristoteles, Formel Doğa, Maddi Doğa, Yaşlılık, Ölüm

\section{Introduction}

According to Aristotle, dying from old age is natural (de Iuv. 472a 16-17, 478b 24-28, 479a32 479b 2). However, given Aristotle's account of nature as the internal principle of change and staying unchanged, it is not obvious how to make sense of natural death. A human being, according to Aristotle, is not potentially a dead body. And there are some passages where Aristotle writes as though getting old is not natural. So, in what sense is dying from old age natural?

In order to answer this question, I will first focus upon Aristotle's account of decay in general, since old age is a kind of decay. I will argue that decay is both natural and unnatural

\footnotetext{
* Ph.D, Bilkent Üniversitesi, İnsani Bilimler ve Edebiyat Fakültesi, Felsefe Bölümü, Ankara. tufan.kiymaz@bilkent.edu.tr
} 
according to Aristotle. The nature of a thing has two aspects, matter and form, and decay is materially natural but formally unnatural. Likewise, natural death is death caused by old age and although getting old is never formally natural, it is materially natural. However, getting old does not have the same mechanism as inorganic decay, such as wine's turning into vinegar, but it is a result of the materially natural decay of the lungs, which leads to the exhaustion of the vital heat. This mechanism will be explained in the last section.

\section{Natural Decay}

Nature, according to Aristotle, is an internal source/principle of change and rest (Ph. 192b 13). A common property of natural things is that, because they have an internal principle of motion and rest, they behave in characteristic ways unless there is impediment:

“... when a certain thing comes to be always or for the most part, it is not a concurrent happening, nor the outcome of luck. Now with that which is natural it is always thus if there is no impediment" (Ph. 199b 24-27).

And, this propensity to act in characteristic ways accounts for the regularities in nature:

"The things mentioned, and all things which are due to nature, come to be as they do always or for the most part, and nothing which is the outcome of luck or an automatic outcome does that: We do not think that it is the outcome of luck or coincidence that there is a lot of rain in winter, but only if there is a lot of rain in August; nor that there are heatwaves in August, but only if there is a heatwave in winter. If, then, things seem to be either a coincidental outcome or for something, and the things we are discussing cannot be either a coincidental or an automatic outcome, they must be for something. But all such things are due to nature, as the authors of the view under discussion themselves admit. The 'for something', then, is present in things which are and come to be due to nature" (Ph. 198b 35 - 199a 8).

Rain in winter and heatwaves in August cannot be outcomes from luck, since they occur regularly. So, a teleological explanation is needed; these phenomena must be "for something". And such things that are "for something" are also due to nature. Therefore, these regular occurrences are natural. The "for something" is contained in the form of a substance, and hence its nature, and it explains the regularities.

Decay, putrefaction, the withering of plants, getting old and the resulting death are also regular phenomena. If nature as an internal principle of motion and rest is the explanation of regularities, then decay (both decay in inorganic things and old age) must be due to nature. Accordingly, Aristotle writes that nature is the source of change and rest in respect of various modes of change, and that one of them is growth and decay:

"Some things are due to nature; for others there are other causes. Of the former sort are animals and their parts, plants, and simple bodies like earth, fire, air, and water-for we say that these and things like them are due to nature. All these things plainly differ from things which are not constituted naturally: each has in itself a source of change and staying unchanged, whether in respect of place, or growth and decay, or alteration" (Ph. 192b 9-15). 
There are other passages where Aristotle explicitly states that some forms of decay (putrefaction and old age) are natural:

"All natural destruction is on the way to it [putrefaction], as are, for instance, growing old or growing dry. Putrescence is the end of all these things, that is of all natural objects, except such as are destroyed by violence: you can burn, for instance, flesh, bone, or anything else, but the natural course of their destruction ends in putrefaction" (Mete. 379a 4-8).

"As to the reason why all must die some time - not, however, at any chance time but, when natural, owing to old age, and, when unnatural, to violence" (De iuv. 472a 16-17).

So far, so good. Regularities are explained by the notion of nature as an internal principle of motion and rest; and, since decay is also a regular phenomenon, it is deemed natural. However, this is not the whole picture.

\section{Unnatural Decay}

In On the Heavens and Metaphysics $H$, in apparent opposition to the quotes given in the previous section, Aristotle argues that decay is not natural:

"Retardation is always due to incapacity, and incapacity is unnatural. The incapacities of animals, age, decay, and the like, are all unnatural, due, it seems, to the fact that the whole animal complex is made up of materials which differ in respect to their proper places, and no single part occupies its own place" (Cael. 288b 11-19).

"There is difficulty in the question how the matter of each thing is related to its contrary states. E.g. if the body is potentially healthy, and disease is contrary to health, is it potentially both? And is water potentially wine and vinegar? We answer that it is the matter of one in virtue of its positive state and its form, and of the other in virtue of the privation of its positive state and the corruption of it contrary to its nature" (Metaph. H. 1044b29-34, my emphasis).

In the first quote above, Aristotle explicitly states that old age and decay are incapacities and incapacities are unnatural. In the second quote, he writes that wine's decay into vinegar is contrary to its nature. And, he continues:

"It is also hard to say why wine is not said to be the matter of vinegar nor potentially vinegar (though vinegar is produced from it), and why the living man is not said to be potentially dead. In fact they are not, but the corruptions in question are accidental, and it is the matter of the animal that is itself in virtue of its corruption the potency and matter of a corpse, and it is water that is the matter of vinegar. For the one comes from the other as night from day. And all things which change thus into one another must be reduced to their matter, e.g. if from a corpse is produced an animal, the corpse is first reduced to its matter, and only then becomes an animal; and vinegar is first reduced to water, and only then becomes wine" (Metaph. H. 1044b 34-1045a 6, my emphasis). 
Aristotle asserts that wine is not potentially vinegar and a living man is not potentially dead. Turning into vinegar and dying are accidental corruptions. And, hence, according to this quote, decay, like wine's becoming vinegar and an animal's becoming corpse are not due to an internal principle of motion. Which means, at least sometimes, decay is unnatural.

There is an apparent contradiction between the first set of quotes where Aristotle writes that decay is natural and the second set of quotes where Aristotle writes the opposite. So, how can we solve this puzzle? Is decay natural or not? Or, is it possible that it is both natural and unnatural? How can we make sense of this within Aristotle's framework? In order to answer these questions, let us look at Aristotle's accounts of decay more closely.

\section{Vinegar's “Coming from” Wine}

According to Aristotle, a corpse must be reduced to its matter in order to become a living animal again, and vinegar must first be reduced to water in order to become wine again (Metaph. $\mathrm{H}$. 1045a 3-6). Once the animal becomes a corpse and wine becomes vinegar, change in the reverse direction is only possible if the substance is reduced to its matter from the state of decay. This is because, Aristotle claims, corpse comes from animal and vinegar comes from wine in a similar manner that night comes from day (Metaph. H. 1045a 3).

He also writes that water is the matter of wine in virtue of its positive state and form, and matter of vinegar in virtue of "the privation of its positive state and the corruption of it contrary to its nature". This means, water is potentially wine, and vinegar is a state which is contrary to wine. So, vinegar is, in a sense, the privation of wine from water. Aristotle calls these states "contrary states". And, it seems, he uses the night's coming from day as an example of a state's coming from a contrary state, as night is the privation of day (light).

However, this analogy between vinegar-wine and night-day is somewhat problematic, because in the Generation of Animals, when he discusses different senses of "coming from", Aristotle compares day's becoming night with a natural change which does not include contrary states. He distinguishes four senses of coming "from" (For a similar discussion see Ph. 190a 22 ff. Aristotle also analyses several meanings of "coming from" in Metaph. 1023a 26 ff., which is somewhat different from his analysis in Generation of Animals. But, neither in Physics nor in Metaphysics does Aristotle propose an additional sense of the term "from" that is relevant to our discussion of the naturalness of decay):

(i) "night comes from day or a man comes from boy, meaning that the one comes after the other"

(ii) "statue is made from bronze and a bed from wood, and so on in all the other cases where we say that the thing made is made from a material, meaning that the whole is formed from something pre-existing, which is put into shape".

(iii) "a man becomes unmusical from being musical, sick from being well, and generally

in the sense contraries arise from contraries".

(iv) "from slander comes railing and from this fighting, and all these are from something

in the sense that it is the efficient cause". (Gen. An. 724a 20-31)

The sense of "coming from" in (ii) is being made from a material and the sense in (iv) is being caused by an efficient cause. These two senses of "coming from" are not directly related to our discussion about decay, but (i) and (iii) are.

According to (i), boy becomes man in the similar fashion that day becomes night. A boy's turning into a man is not accidental since a boy is potentially a man. So, it seems, night's coming from day is given as an example of a different kind of change than that of wine's 
decaying into vinegar. But, what does "the one comes after the other" mean? It cannot be merely about the temporal sequence of states, because all change and hence "coming from" has the aspect of temporal sequence. The examples that Aristotle gives for the other three senses of "coming from" can well be examples for (i), if it is to be understood as merely temporally coming after. So, if (i) is to be a distinct sense of "coming from," like the other three senses, which apply to some instances of "coming from" and do not apply to other instances, then it must mean more than just coming temporally after. A stricter sense of "coming after" would be a more plausible interpretation of (i): man comes after boy and not the other way around. In this sense, the "coming from" relation is one directional and irreversible. Similarly, in the course of one day (24 hours), the night comes after day and this change is not reversible. This sense is not trivial like merely temporal coming after. For example, the changes mentioned in (iii), namely becoming unmusical from musical and becoming sick from healthy, are not changes that can fall under (i), undestood in this stricter sense of "coming after". According to this interpretation, (i) involves the sense of "coming from" which is irreversible, but also, as the examples given by Aristotle suggest, natural.

One might object that, contrary to my interpretation, the changes in the sense of (i) are not irreversible. For (i), Aristotle gives the example of man's coming from boy, but of course boy comes from man too. However, this does not mean that the relation in (i) is reversible. Boy comes from his father but the father does not become the boy. In other words, the father and the son can coexist, but the examples in (i) are not like this: boy-state and man-state cannot coexist in a person and day-state and night-state cannot coexist in a day. During a lifetime the change of man is only from boy to adult man, and then the man dies; and during the 24 hour day, the change is always from day to night, and then the 24 hour day ends.

The examples in (i) are of natural changes but the examples in (iii) are all unnatural and necessarily so, since (iii) is the sense in which a state comes from a contrary state. Two contrary states cannot be in one nature. As we have seen above, in Metaphysics $H$, Aristotle asks the question "how the matter of each thing is related to its contrary states" and his answer is that "it is the matter of one in virtue of its positive state and its form, and of the other in virtue of the privation of its positive state and the corruption of it contrary to its nature". So, "coming from" in the sense of (iii) is unnatural since it is due to contraries, but the examples in (iii) suggest that it is (or, at least, it can in some instances be) reversible. A man can become musical again after becoming unmusical and a man can become healthy again after becoming sick.

In the sense of (i) a change is irreversible and it is (or at least can be) natural. In the sense of (iii) a change is unnatural and it is (or at least can be) reversible. Now, the question is this: In what sense does vinegar comes from wine? It is not (ii) or (iv). But, is it (i) or (iii)?

According to (iii), a man's becoming unmusical from being musical and becoming sick from being healthy are similar forms of "coming from": a state's coming from a contrary state. In Metaphysics $H$, for this kind of "coming from", Aristotle gives the example of becoming sick from healthy, and wine's turning into vinegar. But also, he writes, in Metaphysics $H$, that wine's turning into vinegar is similar to day's turning into night; and, night's coming from day is an example of the sense of "coming from" in (i), not (iii). So, apparently, vinegar's coming from wine falls under both (i) and (iii). Which means, wine's decaying into vinegar is a contrary state's coming from a contrary state irreversibly.

This interpretation also helps us to see why vinegar must be reduced to water in order to become wine again: When Aristotle writes in Metaphysics $H$ (1045a 3-4) "all things which change thus into one another must be reduced to their matter" with "thus" he means the sense 
of "coming from" that is both (i) and (iii). So what he argues is that if A and B are contrary states and B comes from A in the sense that B comes (irreversibly) after A, then A can come from $B$ only if $B$ is first reduced to its matter.

But, if decay is "coming from" in both the senses of (i) and (iii), then is it natural or unnatural? The examples Aristotle gives for (i) are natural changes. (iii), on the other hand, is a sense which is only applicable to unnatural change.

\section{Decay: Formally Unnatural and Materially Natural}

The answer I propose it this: Aristotle seems to suggest that decay is natural in some passages and that it is not in other passages, because, according to his view, decay is both natural and unnatural. The nature of a thing has two aspects, material and formal. Things that have a nature are substances ( $P h .192 b$ 33-34) and there are two accounts of nature: nature can be the primary underlying matter of a particular substance or it can be its form (Ph. 193a 27-31). Nature of a substance always has these material and formal aspects and both of them should be taken into account in an inquiry of nature of a thing:

"Since there are two sorts of thing called nature, form and matter, we should proceed as if we were inquiring what snubness is: we should consider things neither without their matter nor in accordance with their matter" (Ph. 194b 13-15).

According to Aristotle, even though both form and matter are essential to nature, the form has a better claim than the matter to be called nature (Ph. 193b 8-9, Part. an. 640b 26-28).

I argue that decay, in Aristotle's view, is always materially natural and formally unnatural for a substance. Aristotle distinguishes between natural and unnatural death and asserts that death is natural when it is due to old age. Old age is natural because, as I will try to establish in the remainder of the paper, it is a form of change which is materially, although not formally, natural. Let us first look at the notion of "material nature".

"That is one way of using the word "nature": for the primary underlying matter in each case, of things which have in themselves a source of their movements and changes" (Ph. 193a 27-30).

Nature is a source/principle of change, but also staying unchanged, but in the above quote Aristotle relates material nature only with change, not with staying unchanged. Aristotle claims that there is no actual remaining unchanged in nature since matter is "an immediate source of contrariety":

“... all things are at all times in a state of transition and are coming into being or passing away. The environment acts on them either favorably or antagonistically, and, owing to this, things that change their situation become more or less enduring than their nature warrants, but never are they eternal when they contain contrary qualities; for their matter is an immediate source of contrariety, so that if it involves locality they show change of situation, if quantity, increase and diminution, while if it involves qualitative affection we find alteration of character" (De long. et brev. vit. 465b 26-34).

Matter always acts towards dissolution, but form counteracts and holds the contraries in matter together: 
"Further, we must ask what is the force that holds together the earth and the fire which tend to travel in contrary directions; if there is no counteracting force, they will be torn asunder; if there is, this must be the soul and the cause of nutrition and growth" (An. 416a 6-10).

The picture Aristotle draws in the above quote is the following: The matter of animals always contain contraries. Because of these contraries in the matter of animals, there is always a propensity to dissolve. What keeps the matter intact is the soul. Soul is the form of a living being. So, we can generalize from this picture that form is what prevents matter from dissolving.

Material nature is always a principle of change, and formal nature, which can be an internal principle of both change and rest, suppresses some aspects of the material nature in order to keep the substance from dissolving. So, decay is materially natural for the animal, but it is not formally natural. Now we can make sense of Aristotle's apparently contradictory remarks about decay. When he says that decay is natural, he means "materially natural" and when he says that decay is unnatural, he means "formally unnatural".

According to this interpretation, formal nature explains growth and material nature explains decay (among other things, of course). Aristotle does introduce the notion of nature as form in order to explain growth:

"That which is growing, as such, is proceeding from something to something. What, then, is it which is growing? Not the thing it is growing out of, but the thing it is growing into. So the form is nature" (Ph. 193b 12-14).

And, when he says that decay is the corruption of the positive state "contrary to its nature" he means the "formal nature" since he also equates the positive state with the form:

"And is water potentially wine and vinegar? We answer that it is the matter of one in virtue of its positive state and its form, and of the other in virtue of the privation of its positive state and the corruption of it contrary to its nature" (Metaph. H. 1044b 31-34).

Wine qua wine is not potentially vinegar. That's why Aristotle writes that wine's decaying into vinegar is "accidental". It is accidental in the sense that it is not part of the formal nature. Similarly, when Aristotle writes that "the incapacities of animals, age, decay, and the like, are all unnatural" (Cael. 288b 15-16) he means that old age is an incapacity for an animal qua animal, and it is not part of the formal nature of the animal. Aristotle does claim (as mentioned above) that formal nature is more important than the material nature:

"The form has a better claim than the matter to be called nature. For we call a thing something, when it is that thing in actuality, rather than just in possibility" (Ph. 193b 8-12).

"For a couch is such and such a form embodied in this or that matter, or such and such a matter with this or that form; so that its shape and structure must be included in our description. For the formal nature is of greater importance than the material nature" (Part. an. 640b 25-29).

Formal nature is more important, but material nature is also indispensable. And, according to our analysis so far, it is responsible for natural decay. So, we can say that death from old age is not formally but materially natural and when Aristotle writes "as to the reason why all must die some time - not, however, at any chance time but, when natural, owing to old age, and, when unnatural, to violence" (De iuv. 472a 16-17) he calls death "unnatural" if it is neither formally 
nor materially natural, and "natural" if it is materially natural. Even if old age is never formally natural it is still due to an internal source of motion, which is the matter.

However, a man's dying of old age is related to but different from the way wine decays into vinegar. Natural death is materially natural but it involves a peculiar process, which is not simply the decay of the body.

\section{Old Age and Natural Death}

Aristotle states that "an animal is by nature humid and warm, and to live is to be of such a constitution, while old age is dry and cold, and so is a corpse" (De long. et brev. vit. 466a 2022). Because of the vital heat, animals are observed to be warm. Life is maintenance of the vital heat and death is its destruction (De iuv. 469b 19-20). The cause of death is the failure of the organ that contains the source of the essential nature, which is the heart in humans (De iuv. 478b 32-33).

According to Aristotle, there are two ways in which fire ceases to exist: extinction and exhaustion (De iuv. 469b 21-30). Extinction is due to opposites and exhaustion is due to heat's becoming excessive, because of a lack of refrigeration and the consuming of its nutriment ( $D e$ iuv. 474b 14-24). Extinction is violent, not natural. But exhaustion is not due to existence of an opposite state (such as cold) but due to the lack of cold. If the fire is not cooled then it exhausts itself.

There is violent death and again natural death, and the former occurs when the cause of death is external, the latter when it is internal, and involved from the beginning in the constitution of organ, and not an affection derived from a foreign source. In the case of plants the name given to this is withering, in animals old age (De iuv. 478b 24-28).

If the vital heat extinguishes due to an opposite, then that would be a violent death, and the things that are opposite to fire (such as anything cold) are external to fire. But exhaustion is due to the nature of fire itself and it occurs when fire is not properly cooled. According to Aristotle, the organs of refrigeration in animals are lungs and gills, and their failure causes exhaustion. So, old age is exhaustion of natural heat due to the inability of the lungs to cool down the heart. But, of course, if the lung is damaged in an unnatural way, such as by an arrow in a battle, that would not be a natural death, even if it is ultimately caused by exhaustion. That's why in the above quote Aristotle writes that natural death is internally caused and it involves "from the beginning in the constitution of organ." The internal cause of natural death that involves from the beginning in the constitution of organ is the material nature of the organ of refrigeration, which is responsible from the natural decay of the organ:

"Youth is the period of the growth of the primary organ of refrigeration, old age of its decay, while the intervening time is the prime of life" (De iuv. 479a 29-31).

"A violent death or dissolution consists in the extinction or exhaustion of the vital heat (for either of these may cause dissolution), while natural death is the exhaustion of the heat owing to lapse of time, and occurring at the end of life" (De iuv. 479a32 - 479b 2).

So, Aristotle claims that:

1. Natural death is due to the exhaustion of the vital heat in old age. 
2. Exhaustion is "due to excess of heat; for, if there is too much heat close at hand and the thing burning does not have a fresh supply of fuel added to it, it goes out by exhaustion" (De iuv. 474b 20-22).

3. Exhaustion of vital heat in old age is due to the natural decay of the organ of refrigeration.

But there seems to be a problem with this picture. Depending on this account, one would think that old age must be warmer than the prime of life. When the lung decays it cannot perform its cooling function and the vital heat becomes excessive and then it uses up its nutriment faster than it is fed and "finally things come to a climax and fire goes out from exhaustion" (De iuv. 479a 14). This suggests that the body must have the most heat just before its natural death. However, Aristotle maintains that old age is not warmer but colder, as we have seen above. In old age, Aristotle writes, "it is just as though the heart contained a tiny feeble flame which the slightest movement puts it out" (De iuv. 479a 19-20). So, how can a "tiny feeble flame” goes out from excess of heat?

The answer is that when Aristotle talks about "excess of heat" that causes exhaustion he takes "excessive" to be relative to the nutriment available to the fire. The vital heat in old age can be less warm than the vital heat in the prime of life but it can still be too warm to be sufficiently fed by the limited amount of nutriment. During old age, even though the organ of refrigeration is not functioning properly, the fire is cooled down and weakened by the insufficiency of nutriment, and that's why old age is cooler than the prime of life. But, of course, the vital heat's gradual cooling down because of the insufficiency of nutriment is compatible with its eventual exhaustion.

\section{Conclusion}

Aristotle makes seemingly inconsistent remarks about the naturalness of decay, including old age. However, according to Aristotle, there are two sorts of nature: formal and material. Decay is never due to formal nature but it is always due to material nature. Natural death, according to Aristotle, is due to the natural decay of the lung. The decay of the lung in old age is materially natural, and it causes exhaustion of the vital heat, which results in natural death. If death is due to a different mechanism than this, then it is unnatural, both formally and materially. 


\section{BIBLIOGRAPHY}

Aristot. An. (= Aristoteles, De anima), Kullanılan Metin ve Çeviri: "On the Soul”. The Complete Works of Aristotle. Ed. J. Barnes. Vol. 1-2. Princeton University Press. 1995.

Aristot. Cael. (= Aristoteles, De caelo), Kullanılan Metin ve Çeviri: "On the Heavens". The Complete Works of Aristotle. Ed. J. Barnes. Vol. 1-2. Princeton University Press. 1995.

Aristot. De long. et brev. vit. (= Aristoteles, De longitudine et brevitate vitae), Kullanılan Metin ve Çeviri: “On Length and Shortness of Life”. The Complete Works of Aristotle. Ed. J. Barnes. Vol. 1-2. Princeton University Press. 1995.

Aristot. De iuv. (= Aristoteles, De Iuventute et Senectute), Kullanılan Metin ve Çeviri: "Life and Death, And Respiration”. The Complete Works of Aristotle. Ed. J. Barnes. Vol. 1-2. Princeton University Press. 1995.

Aristot. Gen. An. (= Aristoteles, De generatione animalium), Kullanılan Metin ve Çeviri: "Generation of Animals”. The Complete Works of Aristotle. Ed. J. Barnes. Vol. 1-2. Princeton University Press. 1995.

Aristot. Metaph. (= Aristoteles, Metaphysika), Kullanılan Metin ve Çeviri: "Metaphysics". The Complete Works of Aristotle. Ed. J. Barnes. Vol. 1-2. Princeton University Press. 1995.

Aristot. Mete. (= Aristoteles, Meteorologica), Kullanılan Metin ve Çeviri: "Meteorology". The Complete Works of Aristotle. Ed. J. Barnes. Vol. 1-2. Princeton University Press. 1995.

Aristot. Part. an. (= Aristoteles, de partibus animalium), Kullanılan Metin ve Çeviri: "Parts of Animals". The Complete Works of Aristotle. Ed. J. Barnes. Vol. 1-2. Princeton University Press. 1995.

Aristot. Ph. (= Aristoteles, Physika), Kullanılan Metin ve Çeviri: Aristotle: Physics, Books I and II. Clarendon Aristotle Series, Eds. J. L. Ackrill and Lindsay Judson. Oxford: Clarendon Press. 1970. 